\title{
限外沪過法のタンパク質食品製造への利用と問題点
}

\author{
野 村 男 次 \\ 九州大学農学部 $=812$ 福岡市東区箱崎六丁目 \\ 昭和56年 8 月 31 日(月） 第28回膜研究会 学士会赤門分館にて講演
}

\section{Application of Ultrafiltration to Producing Protein \\ Food and the Problems Therein}

\section{Danji Nomura}

Department of Food Science and Technology, Faculty of Agriculture, Kyushu University, 6-Hakozaki, Higashi-ku, Fukuoka, 812

Work is in progress in Japan on the utilization of ultrafiltration technique for the recovery of protein from milk and soy wheys, crushed potato and minced fish meat drain waters, and so on.

Any significant break through is not yet achieved in this field on the industrial scale application of this technique due to the adsorption of the protein on the membrane surface, resulting in a decrease of permeability and membrane efficiency. This problem needs to be handled on the top priority to popularize industrial scale application of this technique.

Ultrafiltration was applied in a fish soluble manufacturing plant, and indicated that a typical phenomenon of selected affinity exists between membrane surface and some of the components of fish protein soluble.

This finding led to the selection of suitable membranes showing minimum adsorption of protein on the surface, which led to the concentration of fish protein solution with high degree of efficiency through ultrafiltration.

Key words: Adsorption of the protein, Fish soluble, Selected affinity, Minimum adsorption, Mebrane surface

今日は “限外汇過法のタンパク質食品製造への利用と 問題点”について括話をいたします。この場合，ぬとで 説明申し上げますが，洗浄の問題が一番大きい問題です ので,この問題についてはとくに時間をかけて括話いた したいと思います。

先に, 私は会誌 “膜” の 5 巻 4 号に “食品工業, とく 飞タンパク質の濃縮, 分離における膜分離技術の応用” という主題のもと, 限外汇過法のタンパク質食品製造へ の応用を紹介して扮きましたから，皆さん，拉読みにな った方もあるかと思います。，今日，タンパク質食品製造 領域において，実際に工業的規模で，限外沪過が利用さ れているのは, 乳業の領域でありまして, 乳漿の回収に 利用されて扬ります，その他の部分に怙きましては， だいたいに沏いて，研究，あるいは中間試験中というよ
うな段階にあると言ってよいのではないかと思います。 現在, この領域にあるものの中に执いて, 最も成果が望 まれているのは，大豆タンパク質の製造への利用であり まして, これは, 日本でも関係者が真剣に取り組んでお ります。しかし，まだ工業的規模に执いての利用という

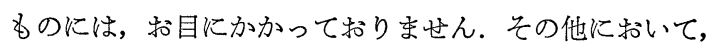
注目されていますのは，扔承知と思いますが，馬鈴薯澱 粉の製造に括ける馬鈴薯水溶性タンパク質の回收といら ことであります，また，後で説明いたしますが，魚肉す り身, あるいは, 魚肉タンパク質製造に対する応用とい うような領域も，非常に望まれるところではないかと思 います．特に，馬鈴薯タンパク質の回収といらことにつ きましては, 馬鈴暮澱粉の生産が，抢承知のように，北 海道で主に行われて括ります関係, 河川の污染の問題と 
224 野村 : 限外沪過法のタンパク質食品製造への利用と問題点

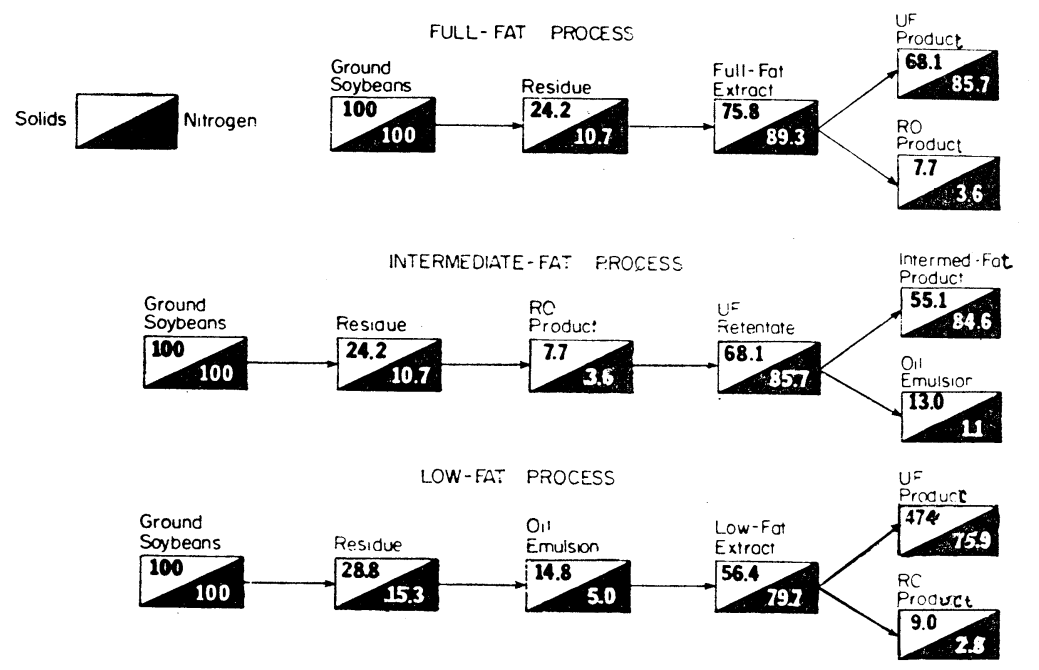

Fig. 1 大豆タンパク質抽出液を膜法で処理したときの固形物および窒素分の収支

共に，非常に注目を引いて拈ります（鮭の産卵期との関 係に执いて)，そこで，この大豆タンパク質の製造と馬 鈴暮タンパク質の製造および回収，それから今ひとつ， 魚肉タンパク質の製造に対する限外沪過の利用が最初申 しましたように研究の対象となっていますが，これらを 工業化するには，いろいろと問題点があります，その問 題点の主体は洗浄の問題でありますが，この問題につい ても多少の実験を行っていますから，これをも含めて, 特に膜の研究の専門の皆さんに, 解決策について何かの サデッションがいただければと思ってお話を申し上げま す.

まず第 1 に，大豆タンパク質工業への利用についてお 話しを申上げます。

大豆タンパク質工業において膜分離法が利用できると すると，その可能性は，この分離法が開発されました初 め頃は，主にホエーの回収を対象においたものでありま したが，現在は，むしろ大豆タンパク質の品質の向上と いったものに目的を沶いた製造への利用が考劣られて拉 ります。ご承知のように，大豆のホエーは，大豆タンパ ク質を水やアルカリで抽出しまして，あとでこれを沈澱 させる，いわゆる “タンパク質の等電点沈澱法”を利用 して製造しているとき生まれるわけであります。このと きに出てくるホエーを限外沪過で濃縮するわけでありま す. 限外沪過に上って，大体に打いて20 40倍位に濃縮 しますと，濃縮液中のタンパク質含量は，大体において $0.3 \%$ くらいのものが，8\%くらいまで濃縮されてまい
ります.この場合，ホエー固形物の中のタンパク質含量 は $18 \%$ から $80 \%$ というょうに上昇してきます。このよう な方法によりますと，タンパク質は選択的に濃縮される わけでありますが，この場合，透過液中には，かなりの 量の低分子固形物が含まれて括りますので，この処理の 後に逆浸透を併用して処理するのが普通であります，大 豆タンパク質液を直接この限外沪過で濃縮する，こうい ら事も考えられているわけであります。このときは，大 体タンパク質濃度を $1.5 \%$ から $3.0 \%$ くらい濃縮する過 程において，透過性物質の $50 \%$ 分分離されるわけであり ます、ご承知のように，この中にトリプシンインヒビタ 一といらようなものも含まれて扮ります。体，分画分 子量 15,000 くらいの限外沪過膜を用いまして, 大豆タン パク質液を固形物 $3 \%$ か $13 \%$ くらい濃縮いたします と, この時タンパク質濃度は大体 6 倍となっているわけ ですが，このような操作におきまして，低分子の糖類と か，あるいは，低分子のその他の有機物質，あるいは灰 分といったものは取り去られていくわけであります。そ の中には大豆タンパク質中の例えばフィチン酸といらよ らなるのも含まれているわけであります。これはご承知 のように，単胃動物の我々にとりましては，栄養上あま りよろしくないものですから，このようなるのは取り除 く方がよく, 私のところでは, アミコン社の PM 30 膜 を用いまして，“フィターゼ”という酥素を併用して 取り去って打ります．非常に容易にこれは取り去ること ができます。この外，限外沪過によりますと，スタキオ 一スとか，あるいはラフィノースといらような，ご承 


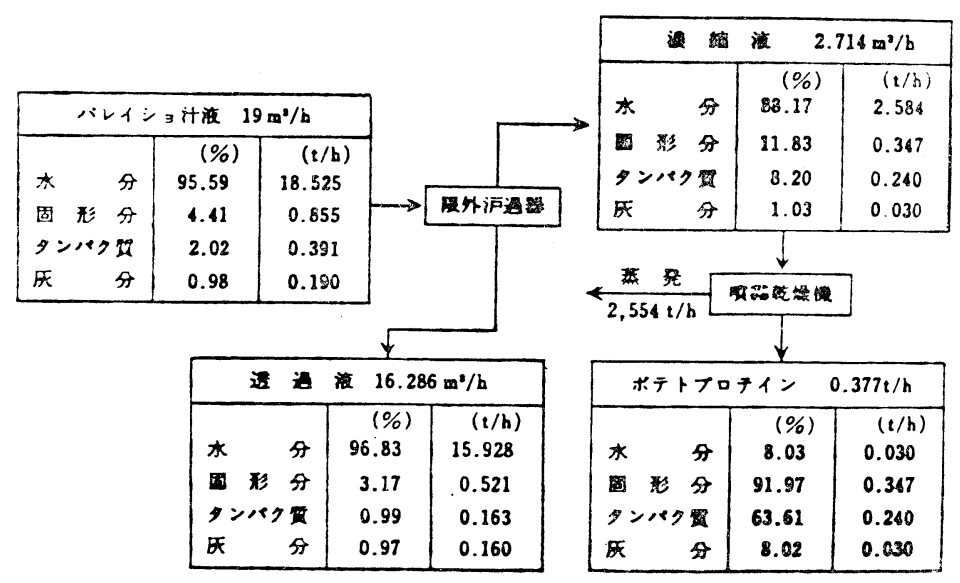

Fig. 2 限外沪過法によって馬鈴暮圧搾汁を処理した場合の物質収支

知のように，我々の膜をふくらますような，いわゆる簡 単に言いますと, ガス発生の材料になるようなもの, こ ういう少糖類も取り除くことが出来ます.

Fig. 1 には，これは私の所の実験ではめりませんけれ ぞも, 大豆の抽出タンパク質を膜処理した場合の, 固形 物打よび窒素分の収支関係がよく示されております。こ こで問題になるのは, タンパク質の収量が計算量より少 ないということであります．このことから，膜に付着す る問題が, 先に申しましたように, 非常に重要な問題を 提供することになるわけですが, これについては後で説 明いたします。

次に馬鈴薯澱粉の製造の場合ですが，ご承知のように， 澱粉の製造では，非常に多くの水を使うわけですが，こ のような水を節約するということ, 同時に排水の中に含 まれているところの可溶性タンパク質のょうなものの河 川污染の問題が, 非常に問題になるわけでありまして, このようなものの回収を，乙かも回収することによって， いくらか資源の再利用ができるとなると, 製造法全体の 経費の節減にも役立つわけであります.そういうような ことで，馬鈴暮澱粉の製造時に生ずる排水，これをどう するかという問題は, 先程申しましたように北海道を中 心に非常な問題を提供しております。これを処理する方 法として，2つの方法が考えられて拈ります，1つはご 承知のように, 馬鈴薯を前もって圧竹, 搾汁しまして, 特に塩類可溶性タンパク質というょうなものを取り去っ ておくというゆき方, 第 2 番目は, 澱粉製造排水の中に 溶けているものを回収するという方法がそれであります. 馬鈴暮を前もって搾汁しまして, それから出てくる汁液
からタンパク質を回収するという場合は, 主に限外沪過 法で行われて扣ります。それから今ひとつ, 排水中に溶 けて萧てられて和りますタンパク質を回収するには, 逆 浸透が主に用いられております。限外沪過の方は, 今申 しましたように，前もって馬鈴薯を圧搾して汁液を採取 するもので，この方法は，その他，リーフプロティンな ぞの製法への利用に考えられているのと同じものであり ます，そこで，今日は限外沪過の話ということになって 扣りますから，限外沪過という面にしぽって括を話を上 げます．膜誌の打世話をしていられる橋本さんがバイオ エンジニアリング社時代に行なわれた実験がありますの で,ここに示しておきます。

Fig. 2 がそれでありますが，これで 1 番問題になるの は, やはり膜污染ということであります。 なお，このよ うな操作を行いました時，今 1 成分的に問題になるの は，灰分が割合多く残ってくること，これをどのように するか，例えば，逆浸透で処理しますと，灰分の含量が だいたい $1 / 3$ の $30 \%$ 台に入ってきます。この外の場合で も同じように, 限外沪過器を透して, 後に残った沪過液 を濃縮しますと，そのようになります，一方，限外汇過 で濃縮された部分に拈いても，やはり灰分は，ここにみ られるように10\%以上とたくさん入ってきます，このよ うに灰分が多く入ってくると，あと製品の利用に打いて 多少の問題を生ずるわけであります，この方法は，いろ いろな本にいろいろと示されていますので, 皆様ご承知 と思いますから, 製法, 装置, その他は略させていただ きます.

次に, 私達が最近行って拈りますフイッシュ・ソルブ 


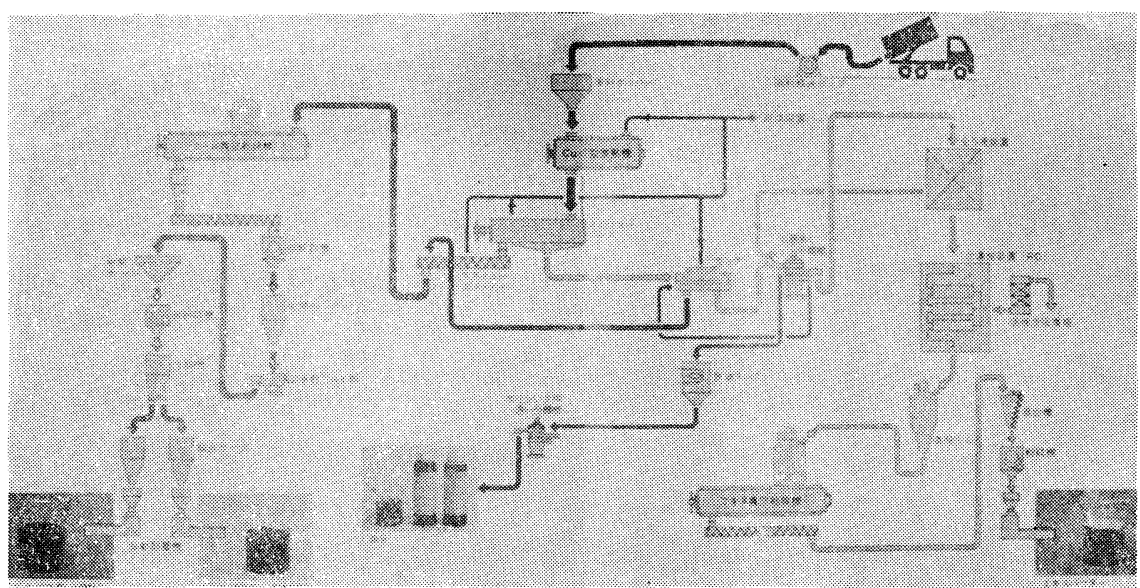

Fig. 3 多目的プラントフローシート

ルの製造について説明いたして抹きます.

これは最近，ご承知のように，魚がだんだんととれ なくなるという事実，しかも日本近海で捕れる魚は， 青いもの，いわゆる解とか，鯖といったものが多くな ること,さらに, 深海魚といったものが問題を提供し て拉りますから，これらの利用対策として行っている ものであります.ささらに，いま，南水洋のオキアミと いったものの取扱問題，それから北海道，あるいは沖 䋲でとれる大きいヒトデの問題などの処理対策にも役 立つものと考えています.

これらをどうかして利用しょうということでありま して，ここでは下関に下瀬食品という会社がありまし て, 害際に工業化ということを志して, 今やって拈り ますので，その実態を少して説明させていただきます。 まず，装置，その他につきまして，スライドを通し て説明いたします. Fig. 3 が製造法のフローシートで 女ります，この製造ですが，ここでは直接関係はあり ませんが，順序として扣話しておきます，您は特種な 蒸煮釜を使いまして蒸煮されます。この蒸煮は，ここ に示されて拉りますが，釜は下瀬食品が特別に考案し て特許にしているようでありまして，その機構につい ては，私充分にまだ研究して打りませんが，非常に興味 ある構造をもって搞ります。れを基本にして製造を行 っているわけであります. Fig. 4 がその特種な蒸煮金で あります。これで括わかりのように，1つの蒸煮釜には

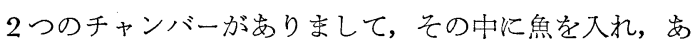
るいは蒸煮しょうとするオキアミやその他，そのような ものを入れるわけであります。これは密封タンクになっ ておりまして, 大体 1 気圧〜 2 気圧くらいの圧力を, 温
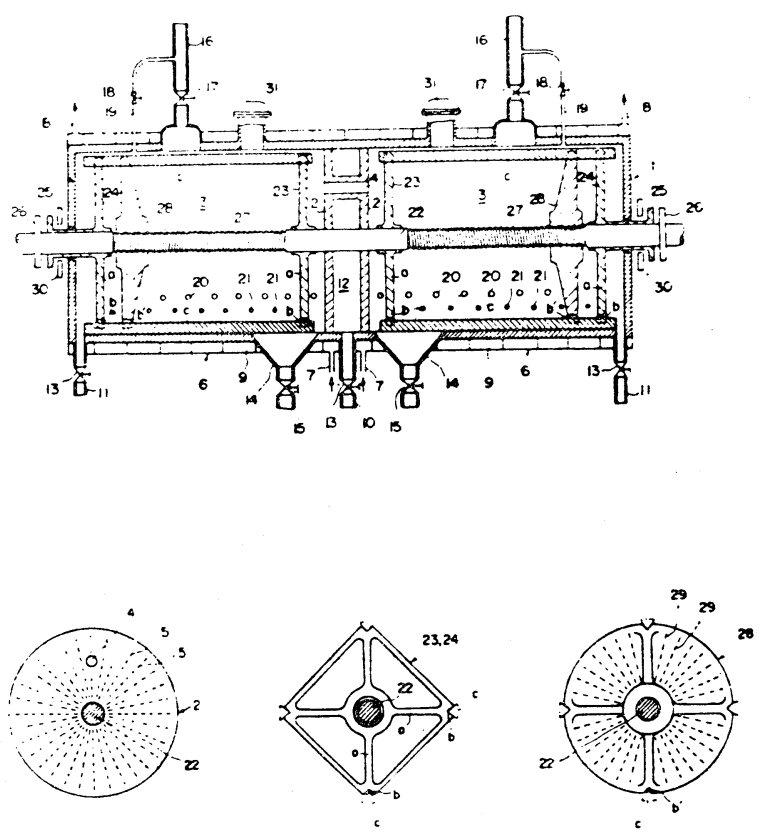

Fig. 4 魚蒸煮釜の構造図

度からいいますと，120〜 $130^{\circ} \mathrm{C}$ が加えられることにな るわけであります。

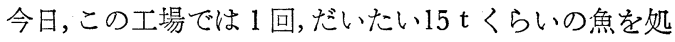
理いたしております．これ(蒸煮金)には，大体50\%相当 ぐらいの水を入れまして, 例光ば $1 \mathrm{t}$ の魚に対して $1 \mathrm{t}$ の水という割合です，そして，その中に䓏気を吹き込み， 回転させながら分解を進めるわけでございます．このと き, 蒸煮と共に, 圧搾抽出が行われます．このようなプ 


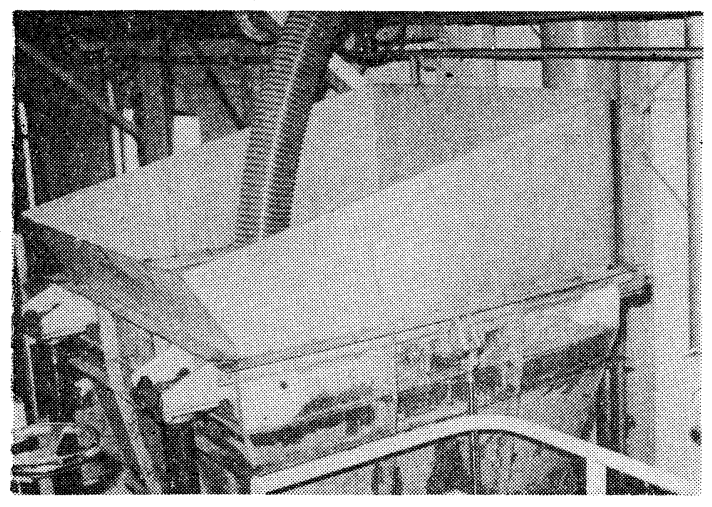

Fig. 5 原料導入口

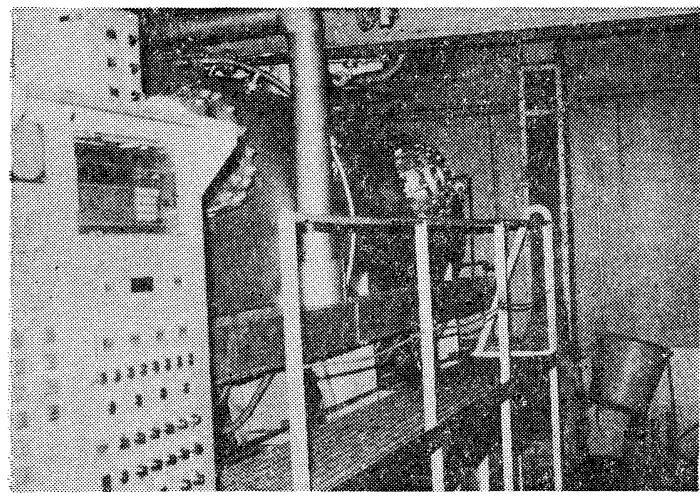

Fig. 6 原料蒸竟釜

レートが両方についているわけでありますが，ここから 液が出てきます。粕の方は逆方向に押し出されまして, ここから採取されるような様式になって打り，連続的に 運転が行われます．会社では，これを今，4基すえて和 りまして，全部で $15 \mathrm{t}$ の魚を1回で処理しております.

Fig. 5 は魚を入れる導入口であります.今申上げた蒸 煮釜が Fig. 6 でございます．ここにはこれが基 4 あり まして，分解液を作って括ります。これは後で申上げま す限外沪過，あるいは逆浸透装置の能力に合せてあるわ けでして，大体 $15 \mathrm{t}$ 処理に 4 時間をかけて打ります。製 造は 1 日大体 2 回行って扣ります。このようにして, 蒸 煮が終わり, 搾出された残渣は, 今一度スクリュープレ スで処理いたして扣ります．抽出液は, ついでデカンタ 一にかけられ，ついで 3 相遠心分離機にかけられ，油分 を分離いたします。.この油を分離した液は，いわゆる工 キスですが，これはつづいて，ミニポアフィルターで精 密沪過を行います. Fig. 7 がその装置であります。これ

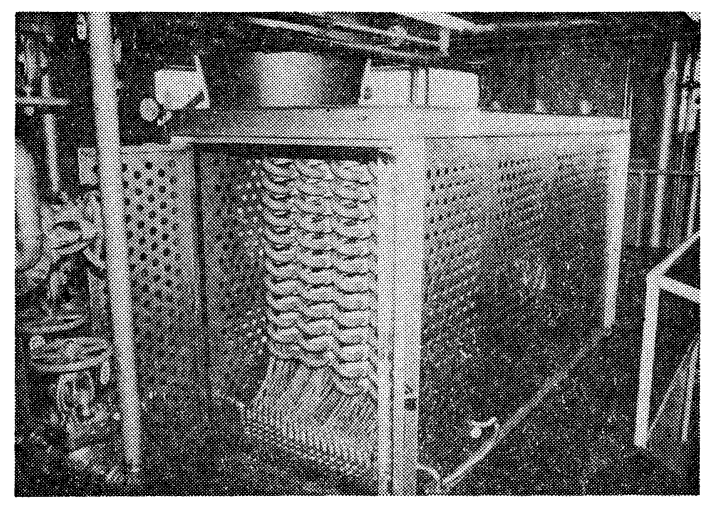

Fig. 7 精密沪過装置

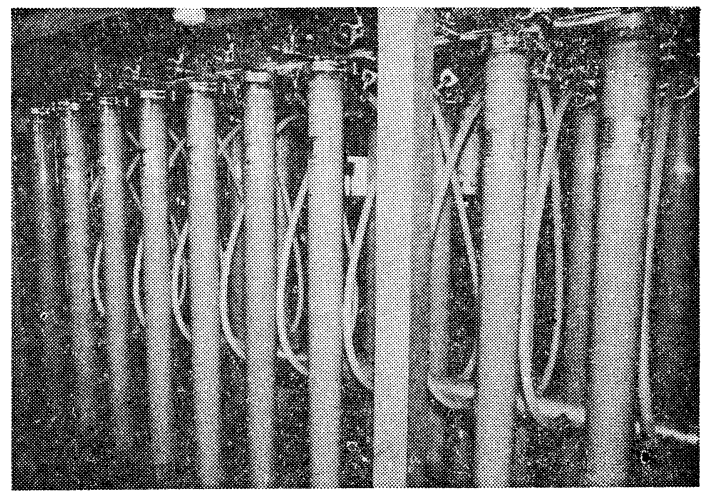

Fig. 8 限外沪過装置

は湯浅電池が施工したものです．この装置とのものはア ミコン社のものではないかと思います。この部分は, 私, 直接タッチしていませんので, よく知りません. 透過液 はここから出てゆきます. 膜の孔径は $0.3 \mu, 1$ 日 2 回 洗浄を行って拉ります. 洗浄には 1 回 2 時間を要してお ります. 1 日 2 回運転を行っていますので， 2 回洗浄と

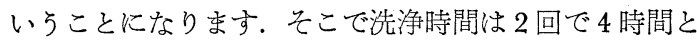
いらことになります。これは現在 8 力月間運転している そうですが，別に問題はないようです. 25本宛，4例に 配して用いて拉ります。つぎに液は限外沪過装置に送ら れます. Fig. 8 はアミコン社のホロー・ファイバー式の ものでありまして，膜にはアミコンの GM-80 という のを用いて和ります。これは和承知のように, 分子量分 画 8 万のbのです. 30 個宛を 4 列に配列して, 現在 120 本使用して拈ります，運転温度はだいたい $45^{\circ} \mathrm{C}$ 位で行 われております。誩いますのは，先に申上げましたよ らに，この部分はクローズド・システムで実施して和り， 


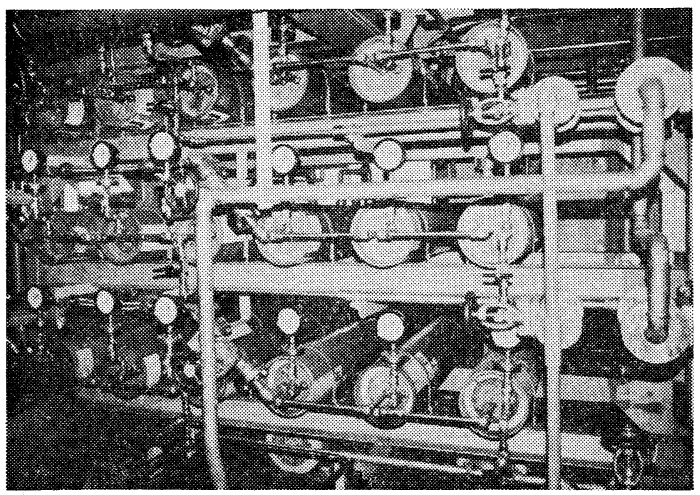

Fig. 9 逆浸透装置

1 番はじめの蒸竟に $120 \sim 130^{\circ} \mathrm{C}$ を用いておりますから， ここで殺菌が行われ，穴の後の操作は割合スムースに， らまくいっているわけであります。このあたりにきます 之, 先にも申しましたように, 大体 $45^{\circ} \mathrm{C}$ 位に温度が下 がってくるのであります.ここで圧力は $1.3 \sim 2.8 \mathrm{~kg} / \mathrm{cm}^{2}$ でした．これも今申上げましたように，始めから最後ま で 4 時間の運転時間内で操作を行っていますから，この ように変化をきたしているわけであります。それから， 洗浄は 1 日 2 回洗浄となるわけです. 1 回の洗浄時間は 2 時間くらいでめります。この場合，先の図面から拉わ かりのように，未透過の部分は集めまして，今 1 回前に か光し，操作を反覆して沏ります，透過部はつぎに逆浸 透にか忛，濃縮を行います。

Fig. 9 が逆浸透の部分であります。体分子量分画 $500, \mathrm{Du}$ pont の B-9 膜を使用しております。食塩の 阻止率95\%，芳杳族ポリアミド系の “Permasep”という 膜であります。モジュールは 3 本を 1 系列とし，18本で 装置を組立てております。ここにきますと運転温度は大 体 $20 \sim 30^{\circ} \mathrm{C}$ といらところまで下がってまいります。運 転圧力は， $28 \mathrm{~kg} / \mathrm{cm}^{2}$ というところで，運転を行ってお ります. 大体ここで固形物含量30～35\%にをで濃縮して 拈ります。な㧥先に申しましょうに，全工程は 4 時間で 終わるようにして打り, 洗浄は 2 回, ここの洗浄は 1 回 3 時間を必要として扣ります，そこで 1 回の運転ははじ めから最後まで， 7 時間で，その中洗浄は 3 時間という ことになって扮ります。これは工場経営上の問題もあり, このようにやっているわけであります，洗浄には多量の 水を必要とします。初期炕いては， $100 \mathrm{t}$ ぐらいの水 を用いていましたが，組合わせをよくし，順序よく処理 することによって現在では大体 $10 \mathrm{t}$ くらいの水で洗浄 ができるようになりました．なお，逆浸透の部分の洗浄

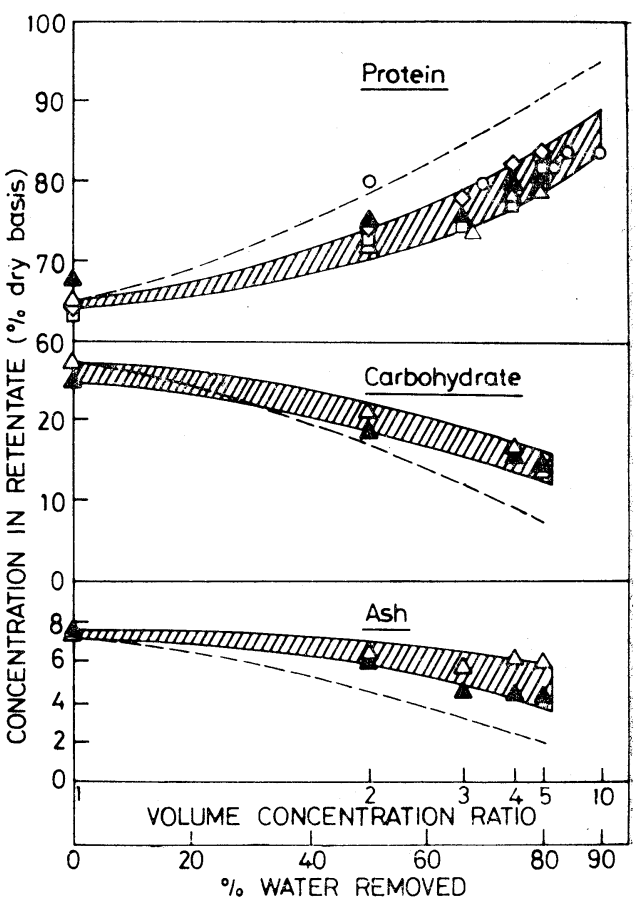

Fig. 10 大豆乳漿の限外沪過処理におけるタンパ ク質, 炭水化物, 灰分の変化

には, 時に酵素剂洗浄を行っておりり,ライオン油脂の製 品を使用しております。

このような方法で実際に運転してみますと，一番大き 、問題は洗浄の問題であります。洗浄には多くの費用も かかりますし，しかも切角，膜法が省エネルギー操作と いわれながら, 洗浄に非常に多くの時間と水と, その他 の要件を必要としますと，ここでのエネルギーの損失が 大きくなります，そこで, 洗浄の問題を考えて装置を組 立てることが必要となります，まず，膜を組込むに当り， 膜質を選ぶことが大切になります。この工場では, 現在 市場にでているほとんぞの膜を試験して打り，結局，さ きに示した膜に落ちついたようです、これが現在のとこ ろ一番よい結果を示したといらことでありまして，それ， らについては，今から説明申上げます。

この場合, 膜とタンパク質との相互関係が一番大きい 問題になるわけでありますが，このようなタンパク質と 膜との関係は，皆梯扮承知の上うに，医用高分子膜に扮 いては非常に多くの研究が行われているようですが，食 品については研究が汪とんどありません，それでこれに ついて少しく拓話申上げます。 
Table 1 限外汇過時のタンパク質の含量と収率

\begin{tabular}{|c|c|c|c|c|}
\hline \multirow[b]{2}{*}{ Membrane } & \multirow{2}{*}{$\begin{array}{l}\text { Mode of } \\
\text { operation }\end{array}$} & \multirow[b]{2}{*}{ VCR } & \multirow{2}{*}{$\frac{\begin{array}{c}\text { Protein } \\
\text { content }\end{array}}{\text { (\% dry basis) }}$} & \multirow{2}{*}{$\frac{\begin{array}{c}\text { Protein } \\
\text { yield }^{c}\end{array}}{(\%)}$} \\
\hline & & & & \\
\hline$X \mathrm{M} 50(45)$ & UF & 5 & 81.2 & 85.2 \\
\hline$X M 50(45)$ & UF & 10 & 84.0 & 83.6 \\
\hline \multirow[t]{3}{*}{$X M 50(20)$} & UF & 5 & 79.5 & 77.1 \\
\hline & re-UF $\left.\right|^{a}$ & 5 & 83.9 & 73.8 \\
\hline & re-UF $\|^{a}$ & 5 & 86.2 & 73.1 \\
\hline \multirow[t]{3}{*}{ PM50(43) } & UF & 5 & 82.1 & 92.4 \\
\hline & re-UF $1^{\mathbf{a}}$ & 5 & 84.1 & 75.1 \\
\hline & re-UF $\|^{\mathrm{a}}$ & 5 & 86.4 & 73.3 \\
\hline \multirow[t]{2}{*}{ PM50(43) } & UF & 5 & 83.9 & 95.0 \\
\hline & re-UF $\left.\right|^{\mathrm{D}}$ & 5 & 87.0 & 90.6 \\
\hline PM50(43) & UF-CD-UF & - & 90.6 & 93.3 \\
\hline
\end{tabular}

a Fibers were cleaned by backflushing between stages.

c Fibers were not cleaned between stages.

Fig. 10は大豆タンパク質を膜処理したときの結果であ ります. タンパク質には, 膜付着といいますか, 吸着と いいますか，そういうものがありまして，それが示され ているわけです，限外汇過で処理した残存液中のタンパ ク質, 炭水化物, 灰分の量を示した図ですが, 限外沪過 処理によって，タンパク質の損失があることがみられま す.これは膜への吸着によるものと思われます，タンパ ク質は膜に付着しやすく，付着によって損失いたします. つぎに大豆タンパク質を PM-50 膜とXM-50 膜で処理 したときの結果を示します (Table 1).

Fig. 11 は大豆タンパク質を PM-50 膜, XM-50 膜 で処理したとき, 膜へタンパク質が吸着する状態を示し たものであります．これで抒わかりかと思いますが， 2 つの膜, PM-50 膜と XM-50 膜とでは, タンパク質の 濃縮に対する対応の状態が違うこと，いわゆる膜への吸 着の状況が異なることであります. XM-50 膜は, 先に 申上げましたように，ポリオレフィン系の膜であります が、これでは 4.5 倍, PM-50 という膜は, ポリスル ホン系の膜でありますが,これでは 4.7 倍というように, 計算上は 5 倍に濃縮したときの結果が現われました，こ こに差がでてきました。このような差が膜の性質の差に よって現われてきます。この関係は, Fig. 11 によく現 われています。

PM-50 膜では, タンパク質濃度が $8 \%$ になりまして も，ほとんど吸着はみられませんが，XM-50 膜では， タンパク質濃度がこの付近になりますと, 大きい吸着が みられます。この場合, 次亜塩素酸液 $(100 \mathrm{ppm})$ 洗浄を 行いますと，PM 膜では変化が現われ，だんだんと吸着 が大きくなってまいります. 洗浄 1 回目よりも, 洗浄 2 回目の方がより大きい吸着性を示しました。この関係は,

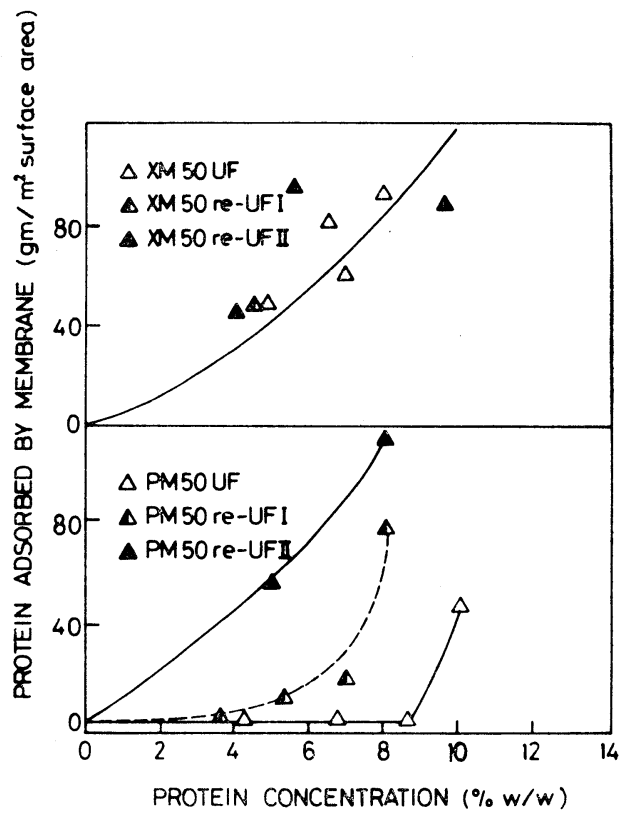

Fig. 11 大豆タンパク質を PM-50 膜 XM-50 膜 で処理したときの吸着量

先にごらんに入れました魚タンパク質をいろいろな膜で 処理した場合にもみられました. やはり膜材料とタンパ ク質の吸着とは非常に関係があること, 吸着の少ない膜 を選び出して使用すれば，洗浄は非常に容易になること がわかりました。この問題は今から膜を開発する上にお いて，非常に重要なことではないかと思います，この図 で，2つの膜が全然異なった吸着現象をみていることは 注目すべきと思います。また，例えば，PM 膜は普通の 状態では吸着現象をみせませんが，次亜塩素酸液で，殺 菌兼洗浄操作を行いますと, だんたんとタンパク質を吸 着しやすくなり，XM-50 膜と同じょうな性質に変わっ てくるとこと, これは膜面が何か変化するのではないか と考觉られすすとして, タンパク質が非常に膜面につ

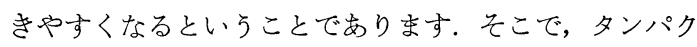
質が付かない膜を選び出すことができると，食品のこの 種濃縮，あるいは分離では非常に都合がよいのではない かと考えるわけであります，今，申上げましたように， 膜の性質によって, タンパク質の吸着性が非常に異なる ということは, タンパク質の回収とか, 濃縮といったよ うな操作において，モジュール膜の開発，さらに膜面に 生成するゲル層, あるいは濃度分極層の洗浄とか, ある いは機能回復とい5よ5なものにおいて, 新しい示唆を 与えるものではないかと考えています.この種の件につ 
230 野村 : 限外沪過法のタンパク質食品製造への利用と問題点

きましては，まだ食品面に括きましては，はじめに申し ましたように，はっきりした結果を出したものは，私ま だ眼にとめることができない状態にあります。しかし先 にも申しましたように. 医用高分子の研究領域では, 研 究が非常に多くありますので，参考になるのではないか と思い，最近いろいろとしらべております，さきに紹介 しました魚のエキス, 抽出液の濃縮に扣きましては, こ の考方方は大変参考になりました.

膜によっては，非常に容易に魚タンパク液によって損 傷をうけるものがあります，そこで，今申しましたよう な関係を是非膜の開発において㫮さん考苀ていただきた いと思います．実際に半工業的に行った実験の段階に打 いて気が付いたわけですが，例えば，オキアミからのタ ンパク質の抽出製造，これは日本では最近燃料が高くな り, 南水洋でこれを捕獲してそのまま日本にもってくる ことが採算上不可能になりつつあり, 現地で処理するこ とが考学られております。この場合, 膜装置を船につみ 込み. 南水洋にゆき，そこで製品を作ることが計画され ているょうであります，この場合，オキアミは赤色の色 素をもっていますが，この色素タンパク質は酶酸セルロ 一ス膜で処理しますとよく吸着されます。そこでオキア ミ処理には酢酸セルロース膜を用いることをむずかしく してあります。

このようなことで, 特種なタンパク質が非常によく吸 着されるというような例が多くめりますので，もっと， このようなことは調べてみなければいけないと思いま 宁.

つぎにこのようなお話をしてきました段階において でてきます洗浄の問題, これは今後, ぞらかして解決し なければならないと思います。これは，限外汇過，ある いは逆浸透といった膜装置を実際に運転してみた上にお いて, 最も問題を提供する領域であります.

先に申しましたように, エネルギー面からみても, 切 角, 利点を持っているにもかかからず, 膜法が実用化に 招いて遅れをとっているのは, 洗浄をどのようにするか という問題, あるいは, 吸着の問題などがまだ解決して いないためであります。

洗浄の目的は, 膜のサニタリー・コンディションをよ くすること，機能回復といらことにあります，サニタリ 一・コンディションをよくするということでは, 膜自身 についてよりも, 装置について考えることが必要となっ てきます、いろいろと洗浄しやすい装置を選び出すこと が大切になります。な技，また膜の面から言いますと，
先に申しましたように，薬剤を使用した場合，膜の性質 が変化する.とくにタンパク質をよく吸着するような膜 面を形成する可能性が生まれるといったようなことにつ いての十分な研究がまだない，といったようなことも大 切なことであります．装置については，デッドスペース をどうするかということも問題になります．特に運転後， 装置を休止すると, その段階に㨟いて微生物の繁殖がデ ッドスペースから生じてくることがあります，膜装置に ゲージやその他の付属物をつけると，どうしてもデッド スペースが多くなり,そこから微生物の繁殖がはじまり ます．そこで如何にしてこのデッドスペースを少なくす るかということになります。これは微生物面から十分に 考臬てゆかるばなりません. 装置中の微生物を少なくす る方法としては，1）増殖抑制物質を使用する 2) 低温 で運転する．3）高温で運転する．4）滞留時間を非常に 短くする.というようなことがいろいろと行われていま すが，どれひとつ取りましても，食品工業においては， これらの導入はむつかしいことであります。例えば, 薬 剤を使用するということになりますと, 食品中に薬剤が 残るといらようなことが抗こりをす．温度を高くすれば， 膜, その他, 装置に対するいろいろな障害が生まれてき ます，また低温にすれば，透過率が悪くなるというょう なことで, いずれを取るとしましても, いろいろと問題 を生じます。

つぎに, 膜機能の維持, 回復ということについてです が，食塩阻止率が15\%，60\%，80\%，94\%という酢酸七 ルロース膜を使用してペクチン液を処理しますと, 阻止 率が15\%，60\%といった膜がかえって機能回復率に打い て劣ることを認めました．これは膜の孔の中に小さい分 子のものが入りまして, 目をつまらせるためではないか と思います. このことは, 実際に魚のタンパク質と処理 した場合, 孔に対して, 砂の上らな小さい粒子をつめる 場合と, 小石のような少し大きい粒子のものをつめる場 合とを考㝋てみました，孔径よりもはるかに大きいと考 えられるタンパク質のゲルを処理した後で, 分子の小さ いタンパク質を処理するというょうにしますと, 割合に 長く, 孔をつまらせることなく, 運転ができることにつ いて先にのべましたが，実際に，それを装置運転におい。 て認めました，そこで装置の組立てに当っては，これを 参考に，実施いたして打りますが，このような現象は， いっもはっきりとみることができました．小分子のもの をはじめから処理しますと，孔が完全につまってしまい， 回復率が非常に悪くなります. それに対して, 少し分子 の大きいものをはじめ処理して, 孔をつめますと, 空間 
ができ，小さいものをはじめにおいて処理したものより も，膜の孔をつまらせることが少ないことがみられます。 このような装置運転に当たっての配虑は, 先にごらんに 入れました魚タンパク質の濃縮に当たりまして，3本の モジュールを1組に組合せる場合，その組合をどのよう にするとよいか，決定するとき，参考にしています。 なお，この他，度々申上げました膜面に対するタンパク 質の付着, 吸着といった問題, このようなものがくっつ くと, 膜の劣化あるいは, 透過率の低下というものが生 じてくるわ忛ですが，このようなトラブルが生ずる原因 となる付着, 吸着というものは, 膜面そのものの性質, あるいは膜材料の性質というものと共に，いろいろなも のが綜合的に関係するものでありますからこれらのこ とを十分に考光に入れて，開発を実施することであり， また使用する場合に沶いても，これを考完に入れて使用 することが大切であります，そこで，ある領域において は, 非常によくゆくものも，ある領ではよくゆかないと いらことがあります。

私達はタンパク質の濃縮を主題に研究を行っています が, タンパク質の付着, 吸着の問題, あるいは膜污染と いうことは，膜との関係をより一層深く追求してゆかな いと，一律に市販されている膜をるってきて，実施する というようなことを行うと，洗浄に非常に多くの時間と 経費を要するというのが現状であります，そこで今から の開発では，これを考宎ねばならないと思います。

膜の洗浄法としましては，いろいろな方法が示されて おります，ゲル層の形成を防止するには，例总ば，スポ ンジボールを流して，スポンジボールの擦洗効果で, 膜 面付着層を洗い流す方法などが，大豆タンパク質処理に おいて行われて打りますが，日本では，先に申上げまし た馬鈴暮澱粉製造時の排水からのタンパク質回収におい て，日立プラントなどがこれを行っています，一般に流 動洗浄法といわれているものも行われております。これ は管内にプラスチックボールを入れ，下部より液を送り， 乱流を作り，ゲル形成を防止するものであります．この 外，間欠瞬間フラッシュ法というものも行われておりま す、しかし，いずれるまだ十分な成果をあげ得ておりま せん，ただ先にも申上げあしたように，この場合でも一 番重要なことは, 膜とタンパク質との間の吸着, または 付着といらことについて, 今少しく研究を進めないと, また，その面から考觉てゆかないと，この問題は解決し ないのではないかと思います。，とくに膜面とタンパク質 の性質との関係については，今から，膜を開発される㫮 様に是非考觉てみていただきたいと思います，これが解

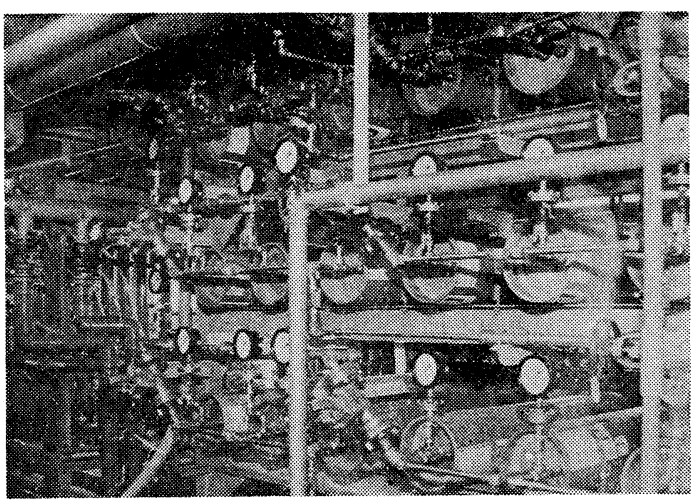

Fig. 12 フイッシュ・ソルブル製造装置

決しない限り，食品工業に怙いて，膜を用いて成果をあ げようとすることは非常に困難ではないか，切角，よい 方法として注目されていながら，このあたりが処理され ないと，省エネルギー法として注目されながら，洗浄な どにエネルギーを要することになり，十分な成果があげ られないことになります。 さらに，これが污染膜の微生 物の原因につながっていますので，これらのことを綜合 して考えていただきたいものであります。

つぎに，以下のべることは付録的なことでありますが， さきにご覽に入れました魚タンパク質，フイッシュ・ソ ルブルの製造についてですが，これは既に製品を市場に

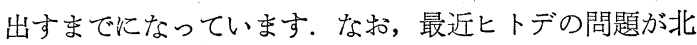
海道でおこっており，また沖縄でも生じております。こ の上うなヒトデをさきに示しました蒝募釜に入れてたき ますと，タンパク質が抽出されてきます。これを濃縮い たしますと，立派なフイッシュ・ソルブルが得られます。 残渣物はカルシウムの豊かな物質であります。また，は じめにふれましたオキアミの問題につきましても，この 装置を船に積んで，南水洋にゆき，現地でこの種のもの を作ろうという計画も岕るようです。このような計画を 進めてゆくためには，やはり今まで申上げました膜への タンパク質の吸着, 付着の問題を今少しく，はっきりさ せないと，いけないのではないかと思います。ささきにご らんに入れました装置 (Fig. 12) は，現在，だいたい8 カ月くらい運転しています。1 1 単位を先にも申しました 上5に，運転 4 時間，洗浄 3 時間とし， 1 日 7 時間を 2 回実施しています。この状態での運転，非常によくいっ て打ります。

な杼，出来上がった製品はかなり分解が進んでいまし 
て, タンパク質というょり.むしろアミノ酸に近いもの であります。製品は天然調味料といったような型で市販 されております。なお，製品を今一度タンパク体にかえ して利用することを考えています，例えば，カマボコの 中に入れるとかして，しまし，この方の研究はまだ十分 にいって拉りません。

膜を使った新しい方法をもって，フイッシュ・ソルブ ルの製造が，このようにできることが明らかになりまし たので, この方法は, 順次各地でフィッシュ・ソルブル の製造へ利用されてゆくではないかと思います.

北海道や韓国などに拈いて，この方法を導入してフィ ッシュ・ソルブルの製造を行いたいといら紹介もありま す. 新しい方法として，この方法は非常に興味のあるも
のであります，実際に，この方法を行ってみますと，今 まで度々申し上げましたように, 膜とタンパク質との結 合，あるいは付着というようなことについて，もっと， はっきりしたこのがわからないと運転がうまくゆかない こと，また．膜をいろいろと選んで実験を行ってみると， 確かにそのような現象がはっきりと認められます。

そこで皆様も今後, いろいろな領域において, このよ うな方法を利用されるときこのことを何かの参考にし ていただけたらと思います。

以上これといったお話にはなりませんでしたと思い ますが，これで終らせていただきます，どうも，有難う 御座いました。

\section{蛙皮膚細胞内のイオン活動度}

\section{Intracellular Ionic Activities inFrog Skin}

W. Nagel , J. F. Garcia-Diaz, and W. McD. Armstrong: Department of Physiology, Indiana

University School of Medicine, Indianapolis, Indiana 46223, USA

J. Membrane Biol., 61, 127-134, 1981

微小電極を用いて細胞内電位等を測定する時に artifacts を除去することが困難なことはよく知られている. 著自らの考案する方法で, カエル皮膚を短絡電流を行っ た状態で細胞内穿刺を行ない, 膜内外電位差 (Vo), 細 胞内 $\mathrm{Na}^{+}, \mathrm{K}^{+}, \mathrm{C}_{\mathrm{l}}^{+}$活動度 $\left(\mathrm{a}^{\mathrm{i}} \mathrm{Na}, \mathrm{a}^{\mathrm{i}} \mathrm{K}, \mathrm{a}^{\mathrm{i}} \mathrm{Cl}\right)$ を測定 した. まず方法論的に得られた数值の正確さを強調して いる.

定常状態で $\mathrm{a}^{\mathrm{i}} \mathrm{Na} 14 \pm 3 \mathrm{mM}$ ，は $132 \pm 10 \mathrm{mM}, \mathrm{a}^{\mathrm{i}} \mathrm{c}_{\mathrm{c}}$ は18土 $3 \mathrm{mM}$ であった。 また。短絡電流 (Isc) とコン ダクタンス (gt) は平均 $43 \mu \mathrm{A} / \mathrm{cm}^{2}$ および $1.3 \mathrm{mS} / \mathrm{cm}^{2}$ で あった. Amilorideを $5 \mu \mathrm{M}$ で粘膜側より投与すると Isc と Gt は低下する。この時の Voは $-87 \mathrm{mV}$ であ るのに対し, $\mathrm{Cl}$ 感受性微小電極によって測定した細胞 内電位は -65mVであった. amiloride 投与前後で $\mathrm{a}^{\mathrm{i}} \mathrm{Cl}$ は変化はなかった。しかし，この間を通じ， $\mathrm{a}^{\mathrm{i}} \mathrm{Cl}$ は, 細 胞膜内外の電気化学的平衡を越える值を示しており, $\mathrm{Cl}^{-}$の細胞外へのdriving forceを示している. amiloride
を長時間 (30分以上) 入れていると $\mathrm{Cl}^{-}$のdriving force は約 1.4 倍に増加する.もともと, Nernst の式から 計算した $\mathrm{a}^{\mathrm{i}} \mathrm{Cl}$ は $4 \mathrm{mM}$ で，実測では $18 \mathrm{mM}$ である ので, 受動輸送の 4.4 倍の動きがあることになり, amilsride は更にそれを増加させている， $\mathrm{Cl}^{-}$の能動輸 送系の存在を考えなければならない。

$\mathrm{K}^{+}$感受性電極による $\mathrm{a}^{\mathrm{i}} \mathrm{K}$ は電気化学的平衡状態 $(28$ $\mathrm{mM}$ ) より高いのは当然で, 外向きの driving forceを 認める. 表皮側から amiloride を投与し. 次いでそれ を除去すると Vo はー88 から -74 mVへ， $\mathrm{V}_{\mathrm{Na}}$ は一 146 から $-126 \mathrm{mV}$ に減少する。 $\mathrm{a}^{\mathrm{i}} \mathrm{Na} 6.3$ から 8.3 mMに増加する. Amiloride により $\mathrm{Na}^{+}$の細胞内への driving force は増加し, $\mathrm{K}+$ のそれは変化なく, $\mathrm{Cl}^{-}$の 外方への driving force が増加すると思われた. 一方, $\mathrm{a}^{\mathbf{i}} \mathrm{Na}$ は強い減少を示し, Isc は低下することから, $\mathrm{Na}^{+}$ の流入と能動輸送との関係をみるとき $\mathrm{Na}^{+}-$pool の存在 を想定しないわけにはいかない（中村瑞穂・丸茂文昭） 